\title{
Korunan Doğal Rekreasyon Alanlarında Donatı Elemanlarının Tasarımları: Altındere Vadisi Milli Parkı Örneği
}

\author{
Özge Volkan AKSU \\ Doğu Karadeniz Ormancılık Araştırma Enstitüsü Müdürlüğü, 61040/Trabzon \\ Sorumlu Yazar: ozgeaksu1@hotmail.com
}

Geliş Tarihi:10.04.2015

\begin{abstract}
Özet
Kent yaşamının getirdiği sorunlar içerisinde yorulan ve çoğunlukla kapalı mekânlar içerisinde bulunmak zorunda kalan insanların, açık yeşil alanlar kapsamında doğal alanlara, özellikle de milli parklar gibi rekreasyonel potansiyel değerleri yüksek alanlara olan istekleri her geçen gün artmaktadır.

Daha çok kentsel alanlar için ifade edilen donatı elemanları, korunan doğal rekreasyon alanlarında da yoğun olarak kullanılmaktadır. Kent mekânlarında görmeye alıştı̆̆ımız donatı elemanlarının tasarım ve ölçütleri ile doğal alanlara uyumsuz kullanımı, mekânı tanımlamayan, kısmen işlevsel olmakla birlikte estetik olmayan tek tip, küçük ölçekli ama birçoğunun bir araya gelerek oluşturduğu karmaşa gibi çeşitli sorunlar, milli parklarda yer alan donatı elemanları tasarımlarının irdelenmesi konusunu gündeme getirmektedir.

$\mathrm{Bu}$ çalışmada korunan doğal alanlar kapsamında Altındere Vadisi Milli Parkı rekreasyon alanlarında kullanılan 16 farklı donatı elemanının tasarımları 21 kriter ile irdelenerek, bulundukları doğal ortama olan etkileri üzerinde durulmuştur. Ayrıca çalışmada, ortaya çıkan sorunların giderilmesine yönelik çözüm önerileri getirilmeye çalışılmıştır.

Anahtar kelimeler: Rekreasyon, milli park, donatı elemanı, tasarım
\end{abstract}

\section{Design of Equipment Elements in Natural Recreation Areas: Sample of Altındere Valley National Park}

\begin{abstract}
People who get tired because of the daily issues and who have to spend their time in indoors have an increasing desire to natural areas within green outdoors, especially areas with high recreational potentials like natural parks.

Equipment elements, which are generally used for urban areas, are also being used in protected natural recreation areas very densely. Equipment elements that we are used to seeing in urban areas cause a variety of problems like being incompatible to natural areas with their design and standards, being unable to define the environment, being semi functional and non-esthetical, being monotype, small-scaled but causing chaos when combined together, moreover; these problems make examination of equipment elements in national parks a current issue.

In this study, within the preserved natural areas, 16 different equipment elements' design, which are used in Altındere Valley National Park recreation areas, have been examined according to 21 criteria and their effects on the environment have been focused. Moreover, solutions to emergent problems are proposed.
\end{abstract}

Keywords: Recreation, national park, equipment element, design

\section{Giriş}

Korunan alanlar, geçmişte yalnızca insan faaliyetlerinin yasaklandığı ya da sınırlandığ alanlar olarak algılanırken günümüzde artık bilimsel değeri yanında estetik değeriyle de koruma altında bulunan, sahip oldukları kaynak değerleri ile rekreasyonel kullanımlara olanak tanıan, toplumun fizyolojik, psikolojik, ekonomik ve sosyal gelişimine katkıda bulunan alanlar olarak görülmektedirler (Surat ve ark., 2014).

Toplumun ve bireylerin doğa ile ruhsal ve bedensel yenilenme amacına yönelik değişik türdeki ilişkileri sonucu oluşan ve günümüzde önemi uluslararası boyutlara ulaşmış bulunan açık hava rekreasyonu gereksinmelerinin karşılanmasında doğal kaynakların başında ormanlar ve bozulmamış doğa parçaları ile doğal niteliğini koruyabilmiş alanlar (milli park, tabiatı koruma alanı, tabiat park1, tabiat anıtı, özel çevre koruma bölgesi gibi) gelmektedir (Demirel, 1999).

Ülkemizde orman rejimi içerisinde kalan alanlarda rekreasyon/turizm amaçlı kullanılabilecek alanlar yasa gereği belirlenmiştir. $\mathrm{Bu}$ amaçla 1983 tarihli 2873 sayılı Milli Parklar Kanununa göre, koruma statüsü verilen doğal içinde sadece Milli Parklar ve Tabiat Parkları rekreasyon/turizm amaçlarına hizmet edebilecek şekilde belirlenmiş̧tir (Gül ve ark.,2005). 
Günümüzde sosyal, ekonomik, kültürel, teknolojik ve siyasal gelişmelere paralel olarak, özellikle kentleşme eğiliminin ortaya koyduğu olumlu ve olumsuz sonuçlar rekreasyonel/turizm talep ve çeşitliliği konusunda önemli değişim ve gelişmelere yol açmaktadır. Kentsel mekânlarda mevcut açı yeşil alanların nitelik ve niceliklerinin eksikliği veya yetersizliği kent insanını özellikle kente yakın doğal alanlara yönlendirmektedir. $\mathrm{Bu}$ bağlamda kentsel alanlara yakın doğal alanlar, özellikle rekreasyonel açıdan yükssek potansiyele sahip olmas1, mevcut bitki örtüsünün ve yaban hayatının zenginliği, doğal peyzaj çeşitliliği gibi özellikleri nedeniyle kent insanı için önemli cazibe ve çekim merkezleri konumundadır (Akten ve Gül, 2014).

Rekreasyon, "bireyin davranışlarını zihinsel düzeyde de etkileyen çeşitli eylemlerdir" şeklinde ifade edilebilir (Douglass, 1975). Bağımsız ve bağlantısız boş zaman içinde, isteğe bağlı ve gönüllü olarak ferdi veya grup içinde seçerek yapılan etkinlikleri kapsamaktadır. Etkinlikler; zamana (uzun süreli, hafta sonu, günlük), türüne (çok aktif, aktif, az aktif, pasif), ve mekâna göre (açık ya da kapalı) çeşitlilik gösterebilmektedir (Kaya, 2012).

Doğal alan rekreasyon faaliyetlerine; zevk için yapılan çeşitli yürüyüşler, su sporlarıla uğraşma, kamp yapma, buzda paten yapma, dağcılık, balık tutma, yüzme, deniz altı uğraşlar, bisiklete binme, doğa incelemeleri, arkeoloji, mağaracilık, avcilık, atıc1lık, piknik yapma gibi etkinlikler örnek olarak gösterilebilir (Karaküçük,1999).

Arazi ve su kullanımı rekreasyon eylemlerinin çoğunda önemli bir yer tutmaktadır. Bu imkânları ise, ormanlar sağlamaktadır. Ormanların rekreasyonel ve turizm değerleri, bütün dünyada farkına varılmaya başlanmıştır (Sun ve Walsh, 1998; Hill ve Courtney, 2006).

Kullanım açısından orman rekreasyon eylemleri; yoğun ve az yoğun (dağınık) olarak planlanabilmektedirler. Yoğun eylemler oldukça merkezîleştirilmiş ve kullanım için geliştirilmiş alanlar için de uygulanmaktadır (piknik ve kamp yapmak vb.). Dağınık orman rekreasyonunu ise, orman içi sularda balık avcılığ trekking gibi herhangi bir alan geliştirilmesine gerek duyulmadan ve geniş alanlar içinde, yapılan eylemler oluşturmaktadır (Çetinkaya, 2008).

Rekreasyonel etkinliklerin yapıldığ korunan alanlar kapsamında milli park alanlarında donatı elemanları yoğun olarak kullanılmaktadır.

Donatı elamanları gerek kentsel gerekse kırsal alan peyzaj düzenlemelerinde kullanılan önemli ögelerdir. Her tasarım ve alanın özelliklerine göre farklılıklar gösterebilen donatı elemanları; milli parklar, tabiat parkları, orman içi dinlenme alanları, kent ormanları gibi rekreasyonel etkinliklere açı alanlarda da yoğun olarak kullanılmaktadır. Doğal alanların ana kaynağı ağaçlar, ormanlık alanlardır. $\mathrm{Bu}$ alanlarda yapılacak düzenlemelerde kullanılacak donatı elemanları malzeme olarak alana uyum sağlaması açısından ahşap olarak seçilmektedir. Ancak salt malzeme seçimi bu alanlar için yapılacak tasarımlarda yeterli olmamaktadır. Tekdüze, sıradan, kent düzenlemelerinde yerel yönetimlerin de kullandığı çöp kapları, aydınlatma elemanları gibi birçok donatı elemanı doğal alanların düzenlemelerinde de rastgele kullanılmakta ve doğa için görsel kirlilik oluşturmaktadır.

İnsanların günlük yaşantılarındaki yorgunluk ve kalabalıktan kaçarak boş zamanlarını dinlenmek ve stres atmak için kullanım ihtiyacı duyduğu doğal alanlarda kullanılan yapısal donatı elemanları oldukça önemlidir. Donatı elemanlarında estetik ve fonksiyonel özelliklerin bir arada ve birbirini tamamlaması aranan bir tasarım özelliğidir. Bilinçli ve uyumlu yerleştirilmiş donatılar insanın ihtiyac1 olan moral ve kolaylikları sağlamaktadırlar (Şahin ve ark., 2005).

Donatı elemanları yaşadığımız kentsel ya da kırsal çevrede rekreasyon amaçlı genel ya da özel kullanım alanlarında yer verilen, konforun ve çevre kalitesinin göstergesi durumundaki oturma, barınma, korunma, kuşatma, ulaşım, danışma, aydınlatma, iletişim, oyun ve spor gibi temel fonksiyonları destekleyip güçlendiren, toplumsal yaşamı kolaylaştırıp kullanıcıların beğenilerini kazanan peyzaj elemanlarıdırlar (Başal ve ark., 1997).

$\begin{array}{llr}\begin{array}{l}\text { Kullanıcıların çeşitli } \\ \text { karşılayan doreksinimlerini } \\ \text { sınıflandırılmasında farklı }\end{array} & \text { yaklaşımlar }\end{array}$


bulunmaktadır. İșlevlerine bağlı olarak yapılan bir sinıflandırmaya göre donatı elemanları; zemin kaplamaları (beton, taş, ahşap, asfalt, tuğla vb), oturma elemanları (banklar, sandalyeler, grup oturma elemanları vb), aydınlatma elemanları (yol aydınlatıcıları, alan aydınlatıcıları vb), işaret ve bilgi levhaları (yönlendiriciler, yer belirleyiciler, bilgi iletişim panoları), sinırlandırıcilar (caydırıcılar, yaya ve trafik bariyerleri vb), su öğesi (süs havuzları, çeşmeler, tulumbalar, kanallar, yangın musluğu vb), üst örtü öğeleri (duraklar, gölgelikler, pergolalar vb), satıs birimleri (kiosklar, sergi pavyonları, büfeler vb), sanatsal objeler (örneğin heykeller) ve diğer objeler (bayrak direkleri, çöp kutuları, posta kutuları, umumi tuvaletler, çiçeklikler, bilet otomatları, bisiklet park yerleri, saatler, parkmetreler, bitkisel öğeler vb) olmak üzere ayrılmıştır (Yıldızc1, 2001).

Donatı elemanları tasarımında işlevsel, psikolojik ve teknolojik ölçütlerin sağlanması gerekmektedir. İşlevsel ölçütler donatı ve insan arasındaki ilişkiyle ilgilidir ve donatı elemanlarının, kullanıcıların antropometrik özelliklerine uygun boyutlandırılması ve donatıların nasıl kullanılacağının kullanıcılar tarafından kolay anlaşılması (işlevsel iletişim) gibi boyutları kapsar. Psikolojik ölçütler, sosyokültürel özelliklere uygun mobilyaların tasarlanması için algılama ve değerlendirme ile ilişkili özelliklerin düşünülmesidir. Psikolojik ölçütler önemlidir. Çünkü toplumların kültürel özellikleri farklıdır ve bu durum donatı elemanlarının biçimlenmesinde de etkili olmalıdır. Teknolojik ölçütler malzeme, üretim ve ekonomiye yönelik ölçütlerdir. Donatı elamanlarının sağlam, işlevsel, biçime uygun malzeme ve teknoloji kullanılarak üretilmesini kapsar (Hacıhasanoğlu, 1991).

Korunan doğal rekreasyon alanları, donat1 elamanları ile bir bütünlük ve anlam kazanırlar. Rekreasyonel etkinliklerin işlevini ve kalitesini arttıran özgün ve farklı donatı elemanları, alanın simgesel ögesi konumuna gelebilmektedirler.

Donatı elemanları tasarımında özgünlüğü yaratan detaylardır. $\mathrm{Bu}$ detaylarda tasarım ölçütleri ile doğrudan ilişkilidirler. Tasarımında; ișlev, estetik, biçim, malzeme, renk, doku ve algılanabilirlik gibi tasarım ölçütleri, özgün ve farklı donatı elemanları tasarımlarının oluşturulmasında etkili olmaktadır (Aksu, 2012).
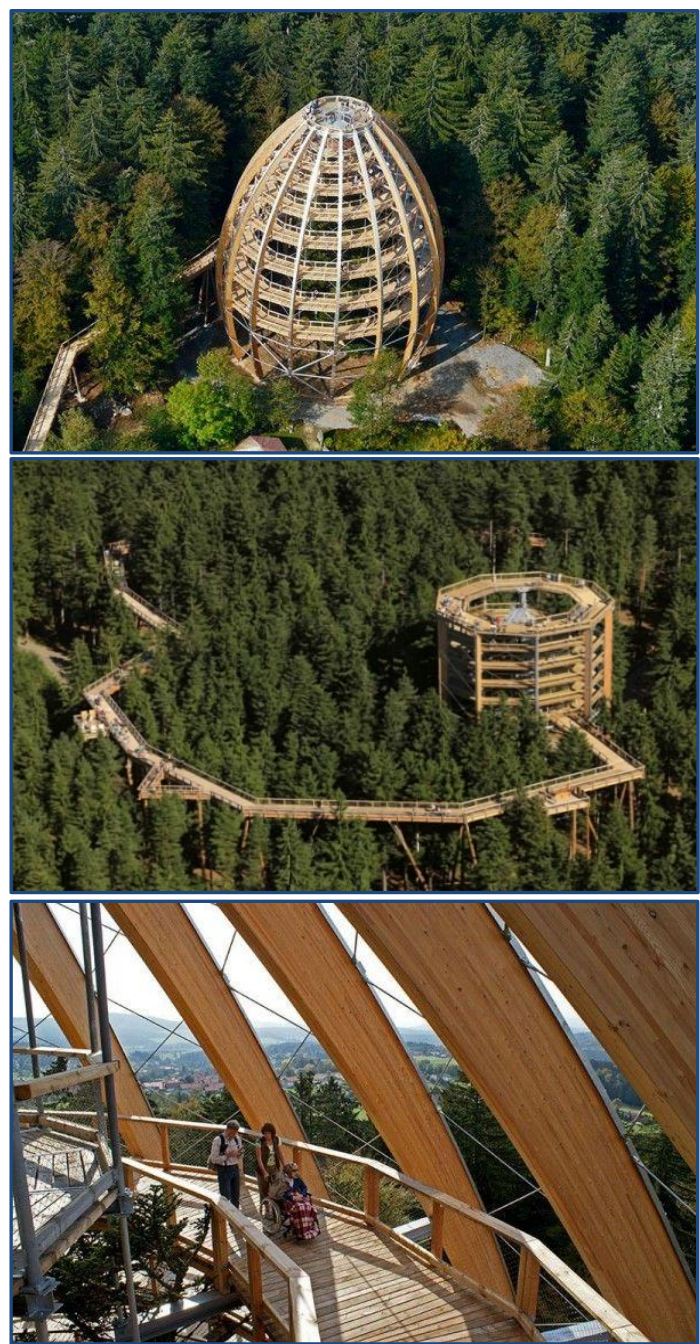

Şekil 1. Bavarion Ormanı Milli Parkı, Almanya (URL1, 2014)

Almanya 'da bulunan Bavarion Ormanı Milli Parkı'nda yer alan gözetleme kulesi $1300 \mathrm{~m}$ yükseklikte ve $44 \mathrm{~m}$ çapında 9 kat olarak yapılmıştır. Engellilerin kullanımına yönelik düzenlemeleri bulunmaktadır. Taşıyıcı sistemleri ahşap malzeme kullanılarak yapılan ve doğaya en az zarar verecek şekilde tasarlanarak inşa edilen gözetleme kulesi, gerek işlevsel gerek se estetik olarak alanın önemli bir simgesel elemanı konumundadır (Şekil 1). 

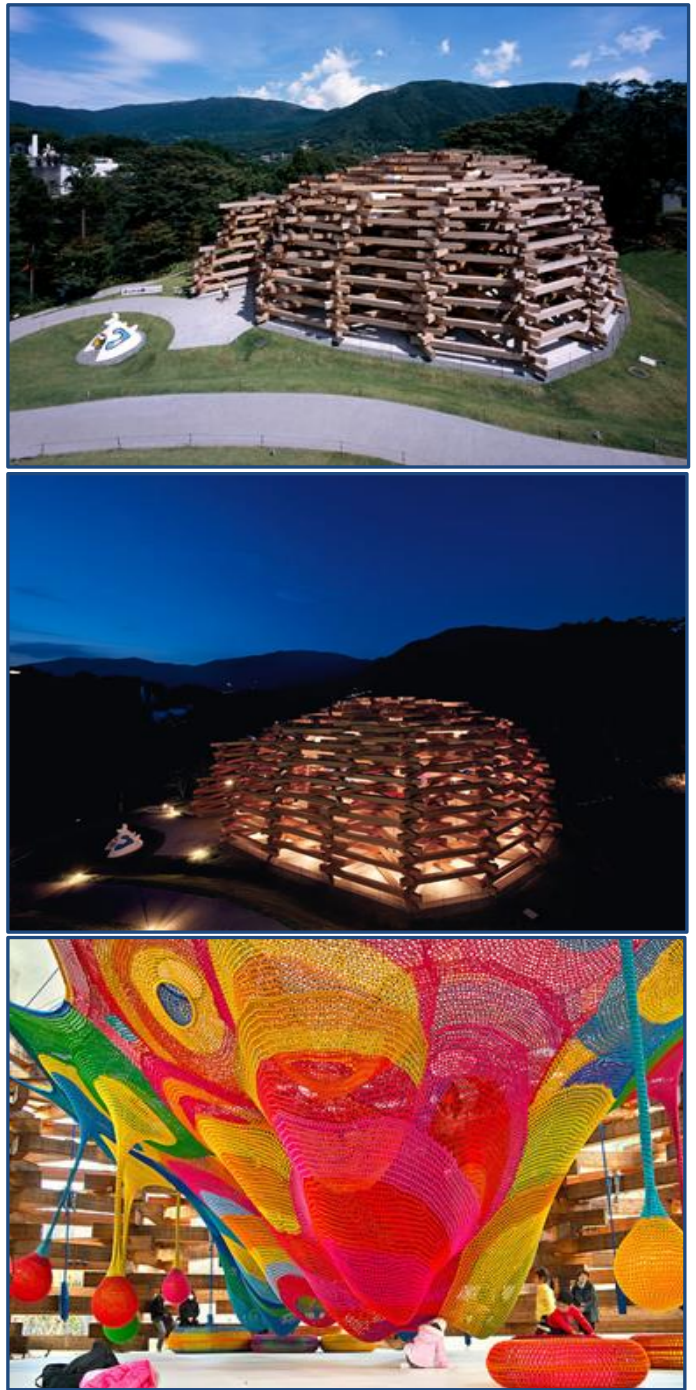

Şekil 2. Fuji-Hakone Izu Milli Parkı, Japonya (URL2, 2014)

Japonya'da bulunan Fuji-Hakone Izu Ulusal Parkı Açık Müzesi'nde bulunan, çocuklar için "ahşap ağ" olarak tasarlanan oyun mekânı bulunduğu alan için özgün bir donatı elemanıdır. Yapımında hiçbir metal malzeme kullanılmamıştır. Renkli file ağlar ile çocuklar için oyun mekânı oluşturulmuştur. Dişardan bakıldığında tamamen ahşap malzeme kullanılarak yapılan, doğa ile uyumlu yarım küre görünümündeki donatı elemanının gece aydınlatması da dikkat çekicidir (Şekil 2).

Litvanya Kursiu Nerija Milli Parkı'nda bölgenin masal kahramanları ahşap malzeme kullanılarak çocuk oyun elemanı, oturma elemanı gibi hem işlevsel hem de estetik amaçlı donatı elemanları olarak tasarlanmışlardır (Șekil 3).
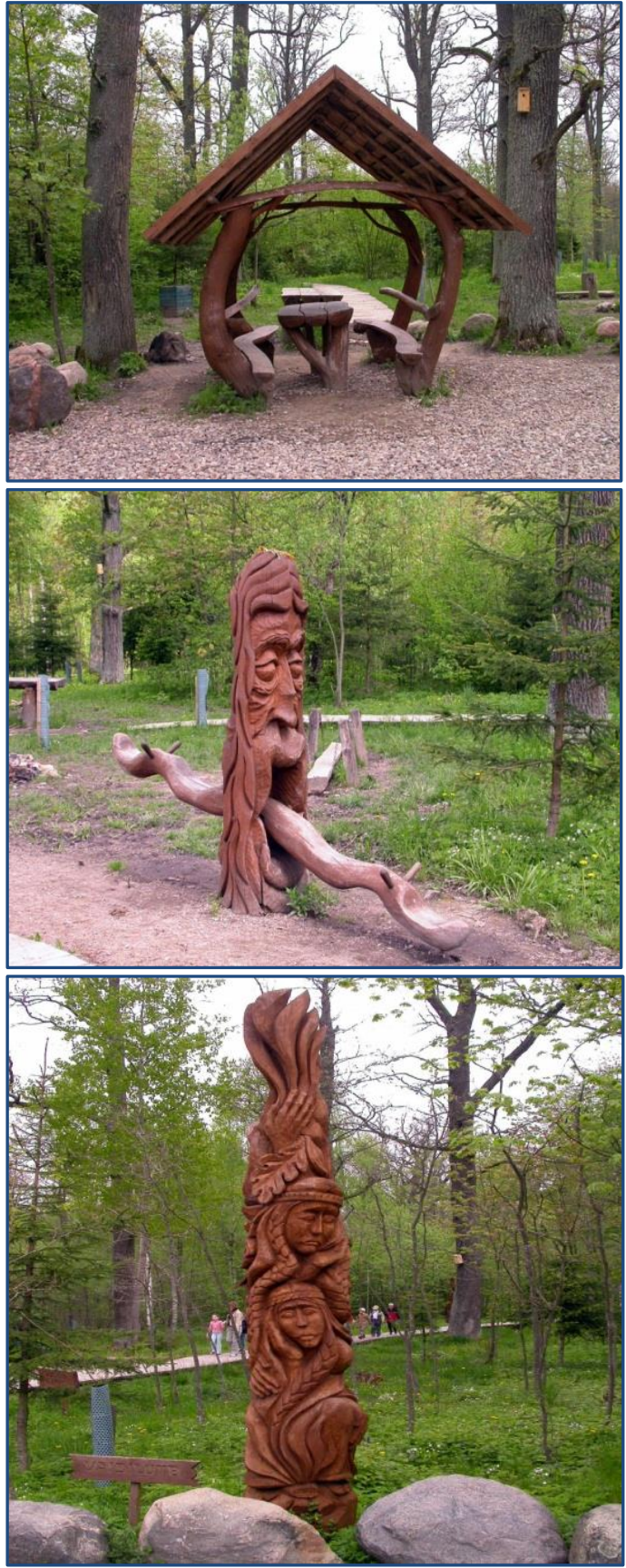

Şekil 3. Kursiu Nerija Milli Park1, Litvanya (URL3, 2014)

Daha çok kentsel alanlar için ifade edilen donatı elemanları, korunan doğal rekreasyon alanlarında da yoğun olarak kullanılmaktadır. Kent mekânlarında görmeye alıştığımız donatı elemanlarının tasarım ve ölçütleri ile doğal alanlara uyumsuz kullanımı, mekânı tanımlamayan, kısmen işlevsel olmakla birlikte estetik olmayan tek tip, küçük ölçekli ama birçoğunun bir araya gelerek oluşturduğu karmaşa gibi çeşitli sorunlar, 
milli parklarda yer alan donatı elemanları tasarımlarının irdelenmesi konusunu gündeme getirmektedir.

$\mathrm{Bu}$ çalışmada korunan doğal alanlar kapsamında Altındere Vadisi Milli Park1 rekreasyon alanlarında kullanılan 16 farklı donatı elemanının tasarımları 21 kriter ile irdelenerek, bulundukları doğal ortama olan etkileri üzerinde durulmuştur. Ayrıca ortaya çıkan sorunların giderilmesine yönelik çözüm önerileri getirilmeye çalışılmıştır.

\section{Materyal ve Yöntem}

Altındere Vadisi Milli Park1; uzun devreli gelişme planında da belirtildiği gibi, rekreasyon potansiyeli yüksek olup, Trabzon ilinin en önemli piknik ve rekreasyon alanlarından biridir (Şekil 4). Ayrıca milli park, alanın bilinirlik düzeyinin (ulusal ve uluslararası) yüksek olmasından dolayı yerli ve yabanc1 her y1l 400.000'den fazla ve sayısı her geçen yıl artan kişi tarafindan ziyaret edilmekte ve çeşitli rekreasyonel etkinliklere olanak sağlamaktadır.

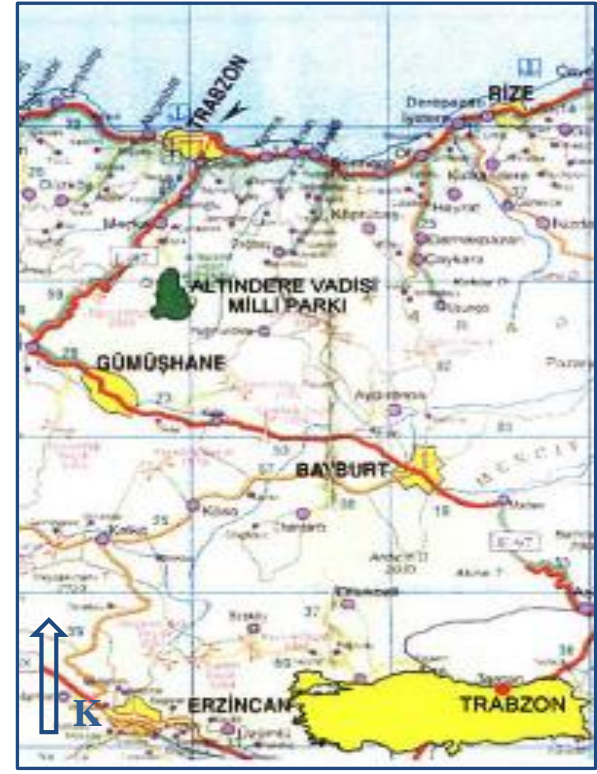

Şekil 4. Milli parkın coğrafi konumu

Maçka Altındere Vadisi Milli Parkı, Trabzon ili Maçka ilçesi sınırları içinde kalmakta ve güneyde Gümüşhane ile sınır oluşturmaktadır. Genel konumu ise $40^{\circ} 42^{\prime}$ $02^{\prime \prime}-40^{\circ} 32^{\prime} 46^{\prime \prime}$ kuzey enlemleri ile $39^{\circ} 38^{\prime}$ $00 "$ - 39 44' 11" doğu boylamları arasında bulunmaktadır. 1987 yılı öncesi Meryemana Araştırma Ormanı olarak değerlendirilen
Ulusal Park alanı 1987 yılında milli park statüsüne alınmıştır. Toplam alanı 4800 ha. olarak belirlenmiştir (Atasoy ve ark., 1985).

Yüksek dağlık arazi niteliğinde olan mili parkın ortalama yükseltisi $2500 \mathrm{~m}$ olup, Trabzon'a 49 km uzaklıktadır. Güneyinde Çakırgöl Dağının eteklerinde Meryemana Deresinin kaynağını oluşturan bir krater gölü bulunmaktadır (Sakıc1, 2005).

Milli parkın rekreasyonel kaynak değerleri; doğal, kültürel ve rekreasyonel peyzaj değerleri olarak irdelenebilir.

\section{Doğal peyzaj değerleri}

Milli park'ın doğal peyzaj değerlerini, jeolojik ve jeomorfolojik oluşumlar, göl ve dereleri ile bünyesinde barındırdığ 1 flora ve fauna oluşturmaktadır. Yükseltiye göre çeşitlilik gösteren türleri ve bu türlerin mevsimsel olarak sergiledikleri görsel kompozisyonlar, panoramik görüşler ve bak1 noktalarıyla etkileyici güzelliklere sahiptir. Milli park, kuşların geçiş güzergâhları üzerinde konumlanmaktadır. Doğu Karadeniz'in doğusunda kuş gözlemcilerinin sık sık geldiği ve fotoğraf çekimi yaptıkları alan bu nedenle, Doğal Hayatı Koruma Derneği ve Bird Life International tarafindan ülkemizin 100 önemli kuş alanlarından birisi olarak ilan edilmiştir. Ayrıca, sahip olduğu botanik, etnografik ve tarihi bileşenleri ile ekoturizm olanăg 1 sağlamaktadır (Düzgüneş, 2009)

\section{Kültürel peyzaj değerleri}

Alanın en önemli tarihsel değerini Sümela Manastırı oluş̧urmaktadır. Turistik açıdan en çok ziyaret edilen Sümela Manastırı büyük bir mağaraya kurulmuş olup Milli Park'ın en önemli odak noktasını oluşturmaktadır. Gerek vadinin alt noktalarında ve gerekse manastıra çıkan yol güzergâhında pasif rekreasyonel etkinliklere olanak vermektedir. Geleneksel mimarisi ve dokusu ile yayla yerleşimleri alanın başka bir kültürel kaynak değerini ortaya koymaktadır.

\section{Rekreasyonel peyzaj değerleri}

Milli parkın en çok ziyaretçi çeken bölümü Sümela Manastırıdır. Dolayısıyla, turizm ve günübirlik faaliyetler parkın kuzeyinde, manastırı ve konaklama tesislerini içine alan bölgede 
yoğunlaşmaktadır. Alanda, Doğa Koruma ve Milli Parklar Genel Müdürlügü denetiminde, özel sektörün işlettiği 40 yatak kapasiteli konaklama üniteleri bulunmaktadır. Milli park alanı "A" tipi ormaniçi rekreasyon alanı olup, 2000 kişi/gün kapasiteli piknik alanlarına sahiptir. Mevcut konaklama ve günübirlik tesislerin bulunduğu alan, gelen ziyaretçilerin vakitlerinin büyük bir bölümünü geçirdikleri bir meydan işlevini görmektedir. Bu alanda artan konaklama ve otopark ihtiyacı doğal yapıyı zorlamaktadır. Bunun yanı sıra konaklama üniteleri, kır lokantası, satıș ünitesi, milli park hizmet binas1 ve restoranın bulunduğu alan, gelen ziyaretçilere hizmet sunma noktasında yetersiz kalmaktadır (Anonim, 2013).

Bu çalışmada Altındere Vadisi Milli Parkı Rekreasyon Alanı'nda yer alan 16 adet donat1 elemanı irdelenmiştir (Tablo 1).

Altındere Vadisi Milli Parkı Rekreasyon Alanı için donatı elemanlarının değerlendirilmesinde 21 tasarım ölçütü kullanılmıştır (Tablo 2).

Tablo 1. Milli park donatı elemanları

\begin{tabular}{ll}
\hline 1 & Giriş ünitesi/Danışma \\
\hline 2 & Bilgi verici tabelalar \\
\hline 3 & Aydınlatma ve elemanları \\
\hline 4 & Restoran ve çevresi \\
\hline 5 & Ürün satış noktaları/Büfeler \\
\hline 6 & Çöp kutuları \\
\hline 7 & Tuvaletler \\
\hline 8 & Piknik alanları ve üniteleri \\
\hline 9 & Oturma ve dinlenme elemanları \\
\hline 10 & Çeşmeler \\
\hline 11 & Bungalovlar \\
\hline 12 & Yürüyüş ve patika yolları \\
\hline 13 & Merdivenler \\
\hline 14 & Otopark \\
\hline 15 & Manzara seyir noktaları \\
\hline 16 & Manastır giriş ünitesi \\
\hline
\end{tabular}

Tablo 2. Tasarım ölçütleri

\begin{tabular}{ll}
\hline 1 & Doğal malzeme kullanımı \\
\hline 2 & Doğaya uyumlu olma \\
\hline 3 & Dayanılı malzeme kullanımı \\
\hline 4 & Bakımlı olma/Temiz olma \\
\hline 5 & İşlevsel olma \\
\hline 6 & Güvenli olma \\
\hline 7 & Ergonomik olma \\
\hline 8 & Ölçü/oran dengesi \\
\hline 9 & Renk uyumu \\
\hline 10 & Malzeme uyumu \\
\hline 11 & Konumunun iyi olması \\
\hline 12 & Görsel zenginlik oluşturma \\
\hline 13 & Simgesel olma \\
\hline 14 & Algılanabilir olması \\
\hline 15 & Etkileyici olma \\
\hline 16 & Farklı olma \\
\hline 17 & Estetik olma \\
\hline 18 & Özgün olma \\
\hline 19 & Diğer donatılarla uyumlu olma \\
\hline 20 & Engellilere yönelik kullanımlar \\
\hline 21 & Yeterli olma-ihtiyacı karşılama \\
\hline
\end{tabular}

Tasarım ölçütlerinin oluşturulmasında Atabeyoğlu ve Bulut (2007) ile Aksu (1998)'nun, tasarım ölçütlerinin değerlendirilmesinde ise Karakaya ve Kiper (2011)'in, ve Aksu (2014)'nun yapmış oldukları çalışmalardan yararlanılmıştır. Tasarım ölçütlerinin değerlendirilmesinde; mevcut değil: 0 puan, mevcut/olumsuz: 1 puan, mevcut/kısmen olumlu: 2 puan, mevcut olumlu: 3 puan, verilerek toplam puanları belirlenmiştir.

Ayrıca 21 tasarım ölçütü için, mevcut olumlu puan üzerinden alınacak maksimum puan $(21 \times 3=63)$, her bir donatı elemanı için puan toplamı ile orantılandırılarak başarı yüzdeleri hesaplanmıştır. Başarı durumları; \% 0-30 ise bașarısız, \% 31-45 ise yetersiz, \% 46-60 ise kısmen başarılı, \% 61-85 ise bașarılı, \% 86-100 ise çok başarılı olarak değerlendirilmiştir. Çalışmanın son aşamasında belirlenen tasarım sorunlarına yönelik öneriler getirilmeye çalışılmıştır.

\section{Bulgular}

Donat1 elemanlarına ilișkin tasarım ölçütlerinin değerlendirilmesi ile oluşan puanlama durumu Tablo 3'de verilmektedir.

Donatı elemanlarına ilişkin tasarım ölçütlerinin durum değerlendirilmesi sonucu 
oluşan toplam puan ve başarı yüzdeleri

dağılımı Tablo 4'de verilmektedir

Tablo 3. Donatı elemanları tasarım ölçütlerine ilişkin puanlar Tasarım Ölçütleri Donatı Elemanları

\begin{tabular}{|c|c|c|c|c|c|c|c|c|c|c|c|c|c|c|c|c|c|}
\hline & & 1 & 2 & 3 & 4 & 5 & 6 & 7 & 8 & 9 & $\begin{array}{l}1 \\
0\end{array}$ & $\begin{array}{l}1 \\
1\end{array}$ & $\begin{array}{l}1 \\
2\end{array}$ & $\begin{array}{l}1 \\
3\end{array}$ & $\begin{array}{l}1 \\
4\end{array}$ & $\begin{array}{l}1 \\
5\end{array}$ & $\begin{array}{l}1 \\
6\end{array}$ \\
\hline 1 & $\begin{array}{l}\text { Doğal malzeme } \\
\text { kullanımı }\end{array}$ & 1 & 2 & 0 & 1 & 0 & 0 & 0 & 2 & 2 & 1 & 2 & 2 & 1 & 1 & 2 & 1 \\
\hline 2 & Doğaya uyumlu olma & 1 & 2 & 1 & 1 & 0 & 0 & 0 & 2 & 2 & 1 & 2 & 1 & 1 & 0 & 1 & 1 \\
\hline 3 & $\begin{array}{l}\text { Dayanıklı malzeme } \\
\text { kullanımı }\end{array}$ & 2 & 2 & 2 & 1 & 1 & 1 & 1 & 1 & 2 & 2 & 2 & 2 & 2 & 1 & 2 & 2 \\
\hline 4 & $\begin{array}{l}\text { Bakımlı olma/Temiz } \\
\text { olma }\end{array}$ & 2 & 1 & 2 & 1 & 1 & 1 & 2 & 2 & 2 & 1 & 2 & 2 & 1 & 1 & 2 & 2 \\
\hline 5 & İşlevsel olma & 1 & 1 & 1 & 1 & 1 & 1 & 1 & 2 & 2 & 1 & 1 & 2 & 1 & 0 & 2 & 2 \\
\hline 6 & Güvenli olma & 1 & 1 & 2 & 1 & 1 & 1 & 2 & 2 & 2 & 2 & 2 & 1 & 1 & 0 & 2 & 2 \\
\hline 7 & Ergonomik olma & 1 & 1 & 1 & 2 & 0 & 1 & 1 & 2 & 2 & 1 & 1 & 1 & 1 & 0 & 2 & 2 \\
\hline 8 & Ölçü/oran dengesi & 0 & 0 & 1 & 1 & 0 & 1 & 1 & 2 & 2 & 1 & 1 & 1 & 1 & 0 & 2 & 1 \\
\hline 9 & Renk uyumu & 0 & 1 & 1 & 1 & 0 & 0 & 1 & 2 & 2 & 1 & 1 & 1 & 1 & 0 & 2 & 1 \\
\hline 10 & Malzeme uyumu & 1 & 1 & 1 & 1 & 1 & 0 & 1 & 2 & 2 & 1 & 1 & 1 & 1 & 1 & 1 & 1 \\
\hline 11 & Konumunun iyi olması & 1 & 0 & 2 & 1 & 1 & 0 & 0 & 1 & 2 & 0 & 2 & 2 & 1 & 0 & 2 & 2 \\
\hline 12 & $\begin{array}{l}\text { Görsel zenginlik } \\
\text { oluşturma }\end{array}$ & 1 & 0 & 0 & 0 & 0 & 0 & 0 & 1 & 1 & 1 & 1 & 2 & 0 & 0 & 0 & 1 \\
\hline 13 & Simgesel olma & 0 & 0 & 0 & 0 & 0 & 0 & 0 & 0 & 0 & 0 & 0 & 0 & 0 & 0 & 0 & 0 \\
\hline 14 & Alg1lanabilir olması & 2 & 2 & 2 & 2 & 1 & 2 & 2 & 2 & 2 & 2 & 2 & 2 & 2 & 2 & 1 & 2 \\
\hline 15 & Etkileyici olma & 0 & 0 & 1 & 1 & 0 & 0 & 0 & 0 & 0 & 1 & 1 & 1 & 1 & 0 & 0 & 1 \\
\hline 16 & Farklı olma & 0 & 0 & 1 & 1 & 0 & 0 & 0 & 0 & 0 & 0 & 1 & 1 & 0 & 0 & 0 & 1 \\
\hline 17 & Estetik olma & 1 & 1 & 1 & 1 & 0 & 0 & 1 & 1 & 1 & 1 & 1 & 1 & 0 & 0 & 0 & 1 \\
\hline 18 & Özgün olma & 0 & 0 & 0 & 0 & 0 & 0 & 0 & 0 & 0 & 0 & 1 & 0 & 0 & 0 & 0 & 0 \\
\hline 19 & $\begin{array}{l}\text { Diğer donatılarla uyumlu } \\
\text { olma }\end{array}$ & 1 & 2 & 1 & 2 & 1 & 0 & 1 & 2 & 2 & 1 & 2 & 2 & 1 & 1 & 1 & 1 \\
\hline 20 & $\begin{array}{l}\text { Engellilere yönelik } \\
\text { kullanımlar }\end{array}$ & 0 & 0 & 1 & 1 & 0 & 0 & 1 & 1 & 0 & 0 & 1 & 0 & 0 & 0 & 0 & 2 \\
\hline 21 & $\begin{array}{l}\text { Yeterli olma-ihtiyacı } \\
\text { karşılama }\end{array}$ & 1 & 1 & 2 & 0 & 1 & 2 & 1 & 1 & 2 & 1 & 1 & 1 & 1 & 0 & 1 & 2 \\
\hline
\end{tabular}

mevcut değil:0 puan, mevcut/olumsuz: 1puan, mevcut/kısmen olumlu: 2 puan, mevcut olumlu: 3 puan

Tablo 4. Donatı elemanlarının puan dağılımları

\begin{tabular}{clcl}
\hline & Donatı elemanları & Toplam Puan & Başarı Yüzdesi \\
\hline 1 & Giriş ünitesi/Danışma & 17 & $\% 27$ (başarısız) \\
\hline 2 & Bilgi verici tabelalar & 18 & $\% 29$ (başarısız) \\
\hline 3 & Aydınlatma ve elemanları & 23 & $\% 37$ (yetersiz) \\
\hline 4 & Restoran ve çevresi & 20 & $\% 32$ (yetersiz) \\
\hline 5 & Ürün satış noktaları/Büfeler & 9 & $\% 14$ (başarısız) \\
\hline 6 & Çöp kutuları & 10 & $\% 16$ (başarısız) \\
\hline 7 & Tuvaletler & 15 & $\% 24$ (başarısız) \\
\hline 8 & Piknik alanları ve üniteleri & 28 & $\% 44$ (yetersiz) \\
\hline 9 & Oturma ve dinlenme elemanları & 30 & $\% 48$ (kısmen başarıl1) \\
\hline 10 & Çeşmeler & 19 & $\% 30$ (başarısız) \\
\hline 11 & Bungalovlar & 28 & $\% 44$ (yetersiz) \\
\hline 12 & Yürüyüş ve patika yolları & 26 & $\% 41$ (yetersiz) \\
\hline 13 & Merdivenler & 17 & $\% 27$ (başarısız) \\
\hline 14 & Otopark & 7 & $\% 11$ (başarısız) \\
\hline 15 & Manzara seyir noktaları & 23 & $\% 37$ (yetersiz) \\
\hline
\end{tabular}


Tablo 4 incelendiğinde donatı elemanlarının başarı yüzdeleri birbirine yakın olup yetersiz ve başarısız düzeydedir, oturma ve dinlenme elemanları ise kısmen başarılı olarak ifade edilebilir.

Doğu Karadeniz Ormancılık Araştırma Enstitüsü Müdürlüğü tarafindan yürütülen "Doğa Koruma Alanlarında Kullanıcıların Rekreasyonel Memnuniyetinin Belirlenmesi: Altındere Vadisi Milli Parkı Örneği" adlı (Aksu ve ark., 2014) proje kapsamında 2014 y1lı yaz döneminde milli park rekreasyon alanında 100 ziyaretçi ile yapılan anket çalışmasının bir sorusunda da ziyaretçilerin mevcut tesis ve donatı elemanlarına ilişkin memnuniyet durumu irdelenmiştir.

Kullanıciların mevcut tesis ve donatı elemanları için memnuniyet durumunun oransal dağ 11 lım Tablo 5'de verilmektedir.
Aritmetik ortalama değerleri; en düşük 2,44 (tuvaletler) en yüksek 3,07 (giriş ünitesi, danışma) arasında yer almaktadır.

Donatı elemanlarına ilișkin tasarım sorunlarının, kullanıcıların donatı elemanlarına ilişkin memnuniyet düzeylerinin kararsı olma ve memnun olmama durumu şeklinde kendini gösterdiği kanısına varılabilir.

Donat1 elemanlarının gerek tasarım ölçütleri ile uzman grup tarafindan irdelenmesi, gerekse kullanıciların memnuniyet düzeylerinin anket yöntemi ile irdelenmesi ile ortaya çıkan veriler benzerlik göstermektedir. Altındere Vadisi Milli Park1 donatı elemanlarına ilişkin bazı görseller Şekil 5'de verilmektedir.

Tablo 5. Tesis ve donatı elemanlarına ilişkin memnuniyet durumunun oransal dağılımı

\begin{tabular}{|c|c|c|c|c|c|c|c|}
\hline & & $\begin{array}{c}\text { Hiç } \\
\text { memnun } \\
\text { değil } \\
\% \\
\end{array}$ & $\begin{array}{c}\begin{array}{c}\text { Memnun } \\
\text { değil }\end{array} \\
\% \\
\end{array}$ & $\begin{array}{c}\text { Ne memnun } \\
\text { ne memnun } \\
\text { değil } \\
\%\end{array}$ & Memnun & $\begin{array}{c}\begin{array}{c}\text { Çok } \\
\text { memnun }\end{array} \\
\% \\
\end{array}$ & $\begin{array}{l}\text { Art. } \\
\text { Ort. }\end{array}$ \\
\hline 1 & Giriş ünitesi/Danışma & 9,0 & 13,0 & 44,0 & 30,0 & 4,0 & 3,07 \\
\hline 2 & Bilgi verici tabelalar & 15,0 & 30,0 & 31,0 & 20,0 & 4,0 & 2,66 \\
\hline 3 & Aydınlatma ve elemanları & 14,0 & 29,0 & 32,0 & 22,0 & 3,0 & 2,71 \\
\hline 4 & Restoran ve çevresi & 15,0 & 31,0 & 36,0 & 16,0 & 2,0 & 2,56 \\
\hline 5 & Ürün satış noktaları/Büfeler & 19,0 & 32,0 & 29,0 & 19,0 & 1,0 & 2,51 \\
\hline 6 & Çöp kutuları & 16,0 & 29,0 & 28,0 & 24,0 & 3,0 & 2,69 \\
\hline 7 & Tuvaletler & 23,0 & 29,0 & 30,0 & 17,0 & 1,0 & 2,44 \\
\hline 8 & Piknik alanları ve üniteleri & 14,0 & 20,0 & 42,0 & 24,0 & 0,0 & 2,76 \\
\hline 9 & Oturma ve dinlenme yerleri & 9,0 & 23,0 & 35,0 & 30,0 & 3,0 & 2,95 \\
\hline 10 & Çeşmeler & 10,0 & 30,0 & 32,0 & 26,0 & 2,0 & 2,80 \\
\hline 11 & Bungalovlar & 17,0 & 25,0 & 38,0 & 17,0 & 3,0 & 2,64 \\
\hline 12 & Yürüyüş ve patika yolları & 9,0 & 22,0 & 43,0 & 25,0 & 1,0 & 2,87 \\
\hline 13 & Merdivenler & 18,0 & 30,0 & 27,0 & 24,0 & 1,0 & 2,60 \\
\hline 14 & Otopark & 18,0 & 33,0 & 27,0 & 18,0 & 4,0 & 2,57 \\
\hline 15 & Manzara seyir noktaları & 10,0 & 33,0 & 27,0 & 18,0 & 4,0 & 2,91 \\
\hline 16 & $\begin{array}{l}\text { Manastır girişi ve dış çevre } \\
\text { düzenleme alanı }\end{array}$ & 6,0 & 19,0 & 45,0 & 26,0 & 4,0 & 3,03 \\
\hline
\end{tabular}




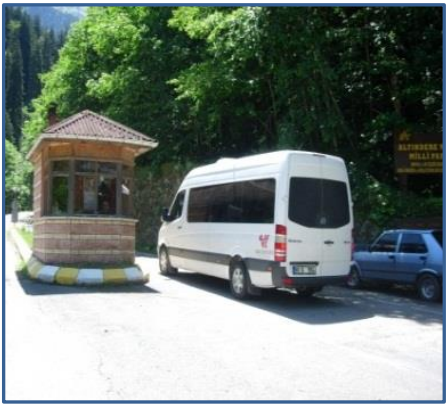

Giriş ünitesi/danışma

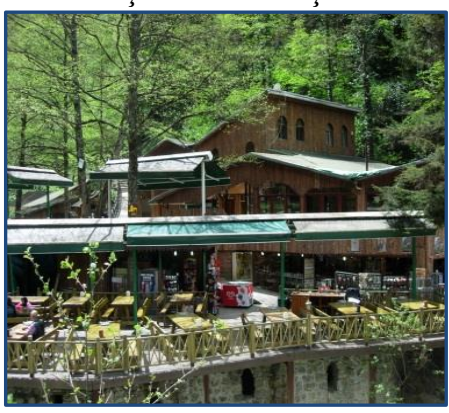

Restoran ve çevresi
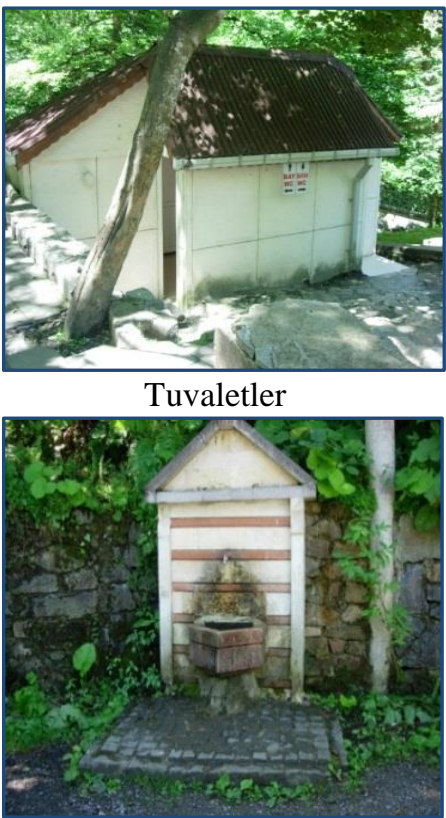

Çeşmeler

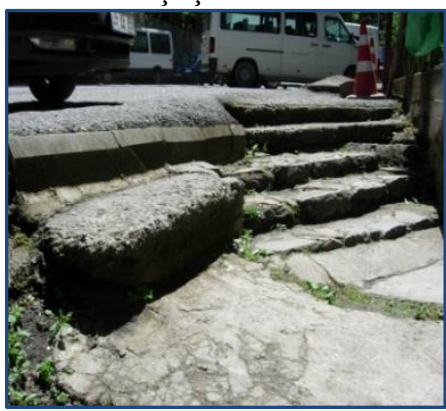

Merdivenler

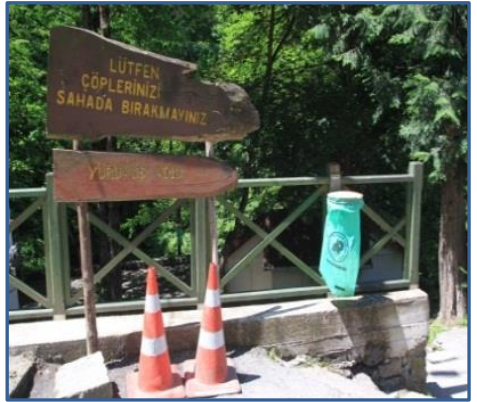

Bilgi verici tabelalar

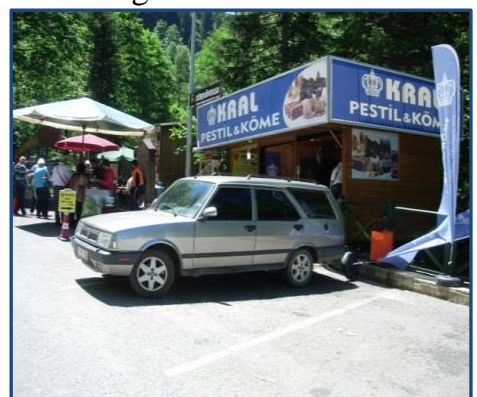

Ürün satış noktaları/büfeler

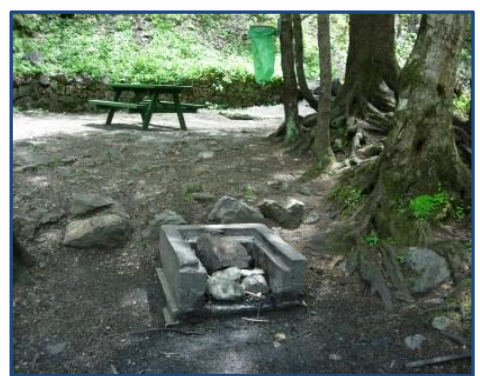

Piknik alanları ve üniteleri

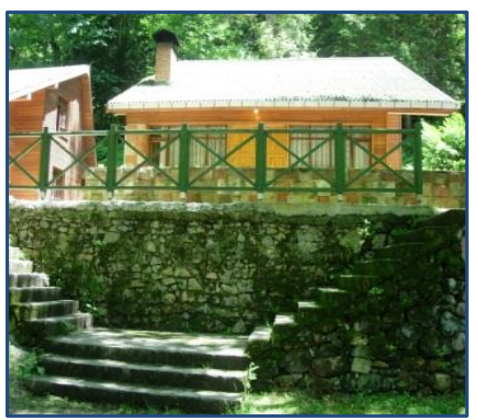

Bungalovlar

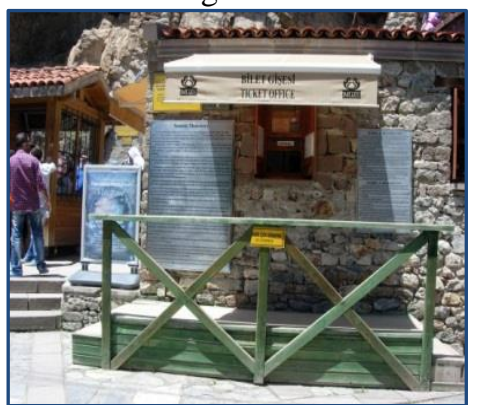

Manastır giriş ünitesi

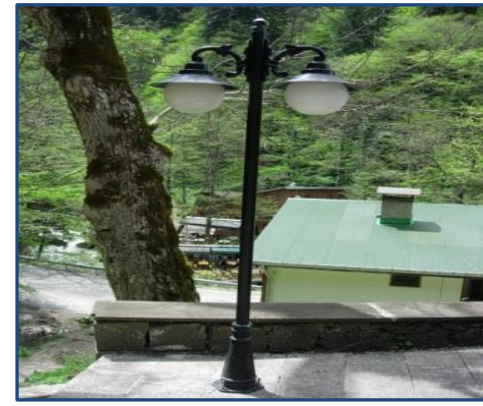

Aydinlatma elemanları

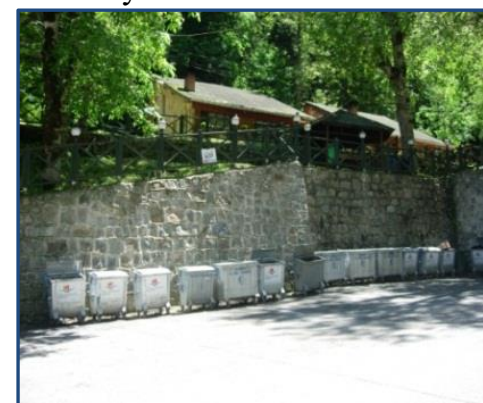

Çöp kutuları

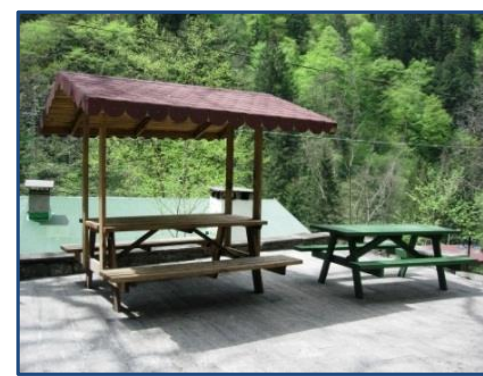

Oturma ve dinlenme alanları

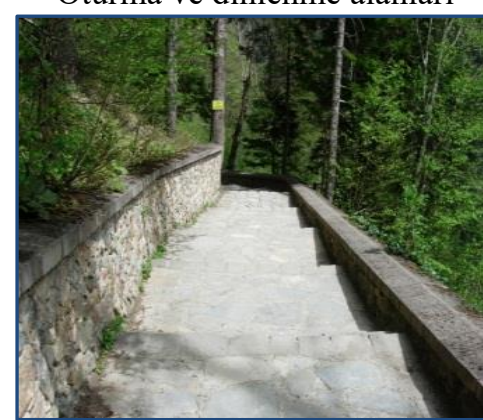

Yürüyüş ve patika yolları

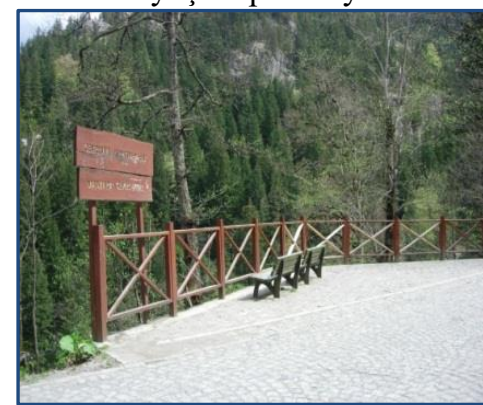

Manzara seyir noktaları

Şekil 5. Bazı donatı elemanlarına ait görüntüler (Orijinal, 2014) 


\section{Sonuç ve Öneriler}

Milli Parklar sahip oldukları doğal ve kültürel güzellikler ile günümüzde rekreasyonel faaliyetlerin en fazla yapıldığ mekânların başında gelmektedir. Dünyada ve Türkiye'de birçok insan, şehirlerin yoğun stresinden, hava kirliliğinden ve trafik yoğunluğundan kurtularak; dinlenmek, gezmek, rahatlamak ve doğal ortamda vakit geçirmek için, koruma altına alınan milli park alanlarını tercih etmektedirler (Kervankıran ve Eryılmaz, 2014).

Bir milli parkın rekreasyonel kalitesini doğal ve kültürel değerler kadar, o rekreasyon alanının doğru planlama, donatı elemanları tasarımları ve kullanımları da etkilemektedir. Küçük ölçekli ve dikkat çekmediği düşünülebilecek birçok donatı elemanın bir araya gelerek oluşturduğu karmaşa, özellikle Altındere Vadisi Milli Parkı gibi dar bir mekâna sıkıştırılmış rekreasyon alanında işlevsel ve görsel sorunlar olarak karşımıza çıkmaktadır.

Altındere Vadisi Milli Park1 Rekreasyon Alanı içerisinde yer alan otopark ve araçların oluşturduğu karmaşa, yine bu alan içerisinde ziyaretçileri karşılayan birçok çöp konteynerlerinin ve büfelerin oluşturduğu görsel kirlilik oldukça dikkat çekicidir. Özellikle dinlenme alanlarında yer alan (bungalovlar çevresi) çok dik, ergonomik olmayan merdivenler, beton malzeme ağırlıklı yer döşeme kaplamaları ile kullanılan çeşitli seri üretim hazır donatı elemanları milli park içerisinde bir kent parkı görüntüsü oluşturmakta, alan doğallığını kaybetmekte, monotonluk ve çevreyle uyumsuz bir görüntü oluşmaktadır.

Atabeyoğlu ve Bulut (2007), Aksu ve Demirel (2012) ve Aksu (2014)'nun yaptıkları çalışmalarda; kentsel dış mekân ve donatılarının kalite yeterliliklerinin puanlama yöntemi ile değerlendirilmesi, yapılan gözlem ve incelemelerin somutlaştırılmasında etkili olmaktadır. Altındere Vadisi Milli Park1 rekreasyon alanında kullanılan bu yöntemle, donatı elemanlarının tasarım ölçütleri irdelendiğinde yetersiz ve başarısız oldukları ortaya çıkmaktadır.

Doğu Karadeniz Ormancılık Araştırma Enstitüsü Müdürlügü tarafından yürütülen "Doğa Koruma Alanlarında Kullanıcıların
Rekreasyonel Memnuniyetinin Belirlenmesi: Altındere Vadisi Milli Parkı Örneği" adlı (Aksu ve ark., 2014) yürütülen proje kapsamında 2014 yılı yaz döneminde milli park rekreasyon alanında 100 ziyaretçi ile yapılan anket çalışmasına bağlı "donatı elemanlarına ilişkin memnuniyet durumu" irdelendiğinde de; kullanıcıların donatı elemanlarına ilişkin memnuniyet düzeylerinin kararsiz olma (ne memnun ne memnun değil) ve memnun olmama durumu şeklinde kendini gösterdiği kanısına varılabilir. Donatı elemanlarına ilişkin kullanıcılar ve anket çalışması ile uzman grup ve tasarım ölçütlerine bağlı değerlendirme yöntemlerine ait veriler benzerlik göstermektedir.

Milli park alanında donatı elemanlarına ilişsin yaşanan sorunlardan biri de kullanılan donatı elemanlarının yeterlilikleri ve ihtiyacı karşılamalarıdır.

Milli park rekreasyon alanı donat1 elemanlarının kullanıcı sayısına bağlı olarak yapılandırılmasına ilişkin bazı standartlar geliştirilerek, gereksiz ya da yetersiz donatı elemanı kullanımı önlenebilir. Donatı elemanları mekân içinde belirli bir düzen içinde yerleştirilmelidir. Kullanıcıların gereksinimlerini karşılamak için her bir eleman ayrı ayrı düşünülmeli ve konumlandırılmalıdır. Birbirinden bağımsız tasarlanmış ve konumlandırılmış elemanlar yer aldıkları mekânda görsel karmaşa ve doğal ortamlarda çevre kirliliği oluşturmaktadır.

Doğal alanda veya mesire alanlarında yapılacak piknik alanları, genel olarak yoğun kullanım için hektara optimal 150 ile 250 kişiye (30-50 piknik ünitesi) hizmet edecek şekilde kurgulanmalıdır. Ancak alanın hassasiyet durumuna ve koruma-kullanma dengesine göre bu yoğunluk hektara optimal 50 ile 100 kişiye (10- 20 piknik ünitesi) hizmet edecek şekilde belirlenebilir. Her 4 veya 5 piknik ünitesi için 1 adet çeşme ve 1 adet çöp kutusu öngörülebilir. Her bir 30 ünite başına 1 adet tuvalet ve büfe veya satış stantları olacak şekilde piknik alanlarından yaklaşık 100-150 m mesafede öngörülebilir. Piknik alanlarında yapılacak çocuk oyun alanlarının büyüklüğü çocuk başına 3-5 m2 olacak şekilde ve 1 ha piknik alanı için minimum $150 \mathrm{~m} 2$ bir alan ayrilabilir (Akten 
ve Gül, 2014). Ancak Altındere Vadisi Milli Park1 Rekreasyon Alanı'nda mekan yetersizliği ve kullanıcı yoğunluğu içerisinde donatı elemanlarına ilişkin doğru planlama ve uygulama çalışmalarının yapılması olanaklı görülmemektedir.

Donatı elemanları için; doğal malzeme kullanımı, doğayla uyumlu olma, dayanıklı malzeme kullanımı, bakımlı/temiz olma, işlevsel olma, güvenli olma, ergonomik olma, ölçü/oran dengesi, renk uyumu, malzeme uyumu, konumunum doğru olması, görsel zenginlik oluşturma, simgesel olma, etkileyici ve özgün olma, estetik olma, engellilere yönelik kullanımlar, diğer donatılar ile uyumlu olma, yeterli olma vb. birçok tasarım ölçütü ile değerlendirilerek yer alacağı mekâna uygun olarak tasarlanmalidır.

Altındere Vadisi Milli park1 rekreasyon alanının doğal, kültürel, tarihsel özellikleri içerisinde önemli bir yer tutan Sümela Manastırı dikkate alınarak, tarihe atıfta bulunan donatı elemanları tasarlanabilir ve alanı temsil edebilecek simgesel elamanlar kullanılabilir.

İyi planlanmamıș turizm ve rekreasyon faaliyetleri milli parkların flora, fauna, hava, su ve kıyı/sahilleri üzerine önemli olumsuz çevresel etkiler oluşturmaktadır. Bu olumsuz etkilerin boyutlarının gün geçtikçe artması, bu alanlarda sürdürülebilir gelişmenin nasıl sağlanabileceği sorusunu akla getirmekte ve bilimsel araştırmaların yapılmasına neden olmaktadır. Milli park rekreasyonel planlamaları, uzun devreli gelişme planları, ziyaretçi yönetimi, kullanıcı memnuniyeti, rekreasyonel olanakların geliştirilmesi vb. yapılan birçok bilimsel çalışmanın yanında, korunan doğal rekreasyon alanları kapsamında donatı elemanları tasarımları da önemli bir konu olarak ele alınarak, bu konuda farkındalık düzeyi yükseltilmelidir.

Kentsel alan donatı elemanı kavramı, korunan doğal rekreasyon alanlarında donatı elemanı kavramı olarakta geliştirilmelidir. Korunan doğal rekreasyon alanları denilince ilk akla gelen piknik üniteleri dışında, uzman gruplar ve kullanıcıların önerileri de dikkate alınarak seri üretim endüstri elemanları yanında, o alan özgü, işlevsel, estetik, yeni, özgün ve bulunduğu mekanı tanımlayan donatı elemanları da tasarlanmalıdır.

\section{Kaynaklar}

Aksu V., 1998. Kent mobilyalarının yer aldıkları mekanlara etkileri üzerine-Trabzon kenti örneği- bir araștırma. Yüksek Lisans Tezi, K.T.Ü, Fen Bilimleri Enstitüsü, Trabzon.

Aksu Ö.V. 2012. Kent mobilyaları tasarımında özgün yaklaşımlar. İnönü Üniversitesi Güzel Sanatlar Fakültesi, Sanat ve Tasarım Dergisi, Cilt 2, sayı 6, 373-386, Malatya.

Aksu Ö.V. 2014. Yaya üst geçitlerinde tasarım kriterlerinin irdelenmesi: Trabzon kenti örneği. İstanbul Üniversitesi, Orman Fakültesi Dergisi, 64 (1)-12-28, İstanbul.

Aksu Ö.V., Kılıç C., Araz N., Düzgüneş E. 2014-2016. Doğa koruma alanlarında kullanıcıların rekreasyonel memnuniyetinin belirlenmesi: Altındere Vadisi Milli Parkı örneği, Proje No: 03.4411.

Akten S., Gül A. 2014. Korunan doğal alanlarda ziyaretçilerin olası etki düzeyleri önlem ve standartlarının belirlenmesi (Gölcük Tabiat Park1 örneği). SDÜ Orman Fakültesi Dergisi, (15), 130-139.

Anonim, 2013. Altındere Vadisi Milli Park1 Uzun Devreli Gelişme Planı, Plan Raporu, Plan karar ve hükümleri. Doğa Koruma ve Milli Parklar Genel Müdürlüğü, $51 \mathrm{~s}$.

Atabeyoğlu Ö., Bulut Y. 2007. Kamu kurum ve kuruluşları dış mekan kalite yeterliliklerinin puanlama yöntemi ile değerlendirilmesi. Süleyman Demirel Üniversitesi Orman Fakültesi Dergisi, Seri A, 92-106.

Atasoy H., Tekin E., Küçük M. 1985. Meryemana Araştırma ormanlarının toprak özellikleri ve haritaları. Ormancılık Araştırma Enstitüsü Yayınları, Teknik Bülten No: 154, Ankara.

Başal M., Memlük Y., Yılmaz O., Kurum E. 1997. Peyzaj Konstrüksiyonu, Ankara Üniversitesi Ziraat Fakültesi Yayınları No:1484, Ankara, 170 s.

Çetinkaya G. 2008. Milli parkların bir rekreasyon alanı olarak düzenlenmesi ve yönetilmesi: Bir model önerisi. Akdeniz Üniversitesi, Sosyal Bilimler Enstitüsü, Yüksek Lisans Tezi, Antalya.

Demirel Ö., 1999. Çoruh Havzası (Yusufeli kesimi) doğal kaynak değerlerinin rekreasyon ve turizm potansiyeli açısından değerlendirilmesi üzerine bir araştırma. Tr. J of Agriculture and Forestry 23(5), 1103-1112.

Douglass R.W., 1975. Forest recreation, forest planning. Faber and Faber Limited, London.

Düzgüneş E., 2009. Altındere Vadisi Milli Park1 (Trabzon)'da koruma değeri İle turizm potansiyelinin saptanmasına yönelik bir yöntem 
yaklaşımı. Yüksek Lisans Tezi, K.T.Ü, Fen Bilimleri Enst., Trabzon.

Gül A., Özgüner H. 2005. Ülkemizdeki korunan doğal alanlarda yönetim zonlarının oluşturulması. Korunan Doğal Alanlar Sempozyumu, Poster Bildiri Kitabı 8-10 Eylül 2005, 151-154, Isparta.

Hacıhasanoğlu I. 1991. "Mimari TasarımKent Mobilyası Tasarımı", 3. Uluslararası Yap1 ve Yaşam Kongresi Bildiri Kitabı, Bursa.

Hill G.W., Courtney P.R., 2006. Demand analysis projections for recreational visits to countryside woodlands in Great Britain. Forestry 79(2):185-200.

Karakaya B., Kiper T. 2011. Hastane diş mekan tasarımlarının Edirne İli örneğinde irdelenmesi. Tekirdağ Ziraat Fakültesi Dergisi, 8(2), 49-64.

Karaküçük S., 1999. Rekreasyon Boș Zamanları Değerlendirme, Gazi Kitabevi, Ankara.

Kaya L.G., 2012. Turizm ve rekreasyonel planlaması ders notları. İnönü Üniversitesi Güzel Sanatlar ve Tasarım Fakültesi, Malatya.

Kervankıran İ., Eryılmaz A. 2014. Isparta ili milli parklarının rekreasyonel faaliyetlerde kullanımı. Marmara Coğrafya Dergisi. Sayı 29, 81-110.

Sakıcı Ç. 2005, Maçka Altındere Vadisi Milli Parkının kaynak değerlerinin ve kullanımının rekreasyonel açıdan değerlendirilmesi, Korunan Doğal Alanlar Sempozyumu, Isparta, 433-440.

Sun D., Walsh D., 1998. Review of studies on environmental impacts of recreation and tourism in Australia. Journal of Environmental Management, 53, 323-338.

Surat H., Surat B.Z., Özdemir M. 2014. Korunan alanların rekreasyonel kullanımı ve yerel halkın farkındalığı: Borçka Karagöl Tabiat Parkı örneği. II. Ulusal Akdeniz Orman ve Çevre Sempozyumu, Isparta.

Şahin C., Üner B., Güntekin E., Şahin H.T. 2005. Odun-plastik kompozitlerin donatı elemanı olarak korunan doğal alanlarda kullanımı. Korunan Doğal Alanlar Sempozyumu Poster Bildiriler Kitab1, 251-253, Isparta.

URL1,

http://stavbaweb.dumabyt.cz/Zahradni- parkovaarchitektura-objekty/Lesni-stromove-prochazkyna-Sumave.html

URL2,

http://commons.wikimedia.org/wiki/File:Playgrou nd_at_Fuji-Hakone Izu_National_Park.jpg

URL3,

http://www.panoramio.com/photo/562498

Yıldızc1 A.C., 2001. "Kent Mobilyaları ve İstanbul'daki Kent Mobilyalarının İncelenmesi",
I. Uluslararası Kent Mobilyaları Sempozyumu, İstanbul. 